\title{
Stopover dynamics of 12 passerine migrant species in a small Mediterranean island during spring migration
}

\author{
Ivan Maggini ${ }^{1}$ (D) Marta Trez $^{1} \cdot$ Massimiliano Cardinale $^{2}$ (D) $\cdot$ Leonida Fusani $^{1,3}$ (D)
}

Received: 16 September 2019 / Revised: 1 February 2020 / Accepted: 12 March 2020 / Published online: 30 March 2020

(c) The Author(s) 2020

\begin{abstract}
Small coastal islands offer landing opportunities for large numbers of migratory birds following long sea crossings. However, they do not always provide sufficient refueling opportunities, thus raising questions about their importance for the success of migratory journeys. Here we analyzed a large dataset collected during 3 years of captures and recaptures of 12 species on the island of Ponza, central Italy, to determine the importance of the island for refueling. Despite the very large amount of birds on the island, only a very small fraction (usually below 2\%) stayed on the island for longer than 1 day. These birds had low energy stores and, in most cases, they were not able to successfully refuel on Ponza. Only two species (Subalpine Warbler and Common Chiffchaff) had a positive fuel deposition rate, possibly as a result of the better suitability of the island's habitat to these two species. We underline that the large use of the island despite the relatively low refueling opportunities may be due to other aspects that it may offer to the birds. Possibly, birds just landed after a long sea crossing may require a short rest or sleep and can find opportunities to do that on the islands, reinitiating their onward flight after just a few hours. Understanding the role of these islands for migratory birds will be important for conservation, since setting priorities for protection might be misled if considering only refueling success as an important variable.
\end{abstract}

Keywords Ponza $\cdot$ Refueling $\cdot$ Resting $\cdot$ "Fire escape" sites $\cdot$ European-African migration

\section{Zusammenfassung}

Rastdynamik von 12 ziehenden Vogelarten auf einer kleinen mediterranen Insel während des Frühjahrszuges

Kleine, küstennahe Inseln bieten großen Zahlen an Zugvögeln nach einer langen Meeresüberquerung Landemöglichkeiten. Jedoch stellen sie nicht immer ausreichend Auftankmöglichkeiten zur Verfügung. Dies wirft Fragen ob ihrer Bedeutung für den Erfolg des Zuges auf. In dieser Studie haben wir einen großen Datensatz analysiert, der Erstfänge und Wiederfänge von 12 Arten über drei Jahre auf der mittelitalienischen Insel Ponza beinhaltet, um die Bedeutung der Insel für das Auftanken zu bestimmen. Trotz der sehr großen Anzahl von Vögeln auf der Insel blieb nur ein sehr kleiner Teil (meistens unter 2\%) länger als einen Tag auf der Insel. Diese Vögel hatten niedrige Energiereserven und waren meistens nicht in der Lage, auf Ponza erfolgreich zuzunehmen. Nur zwei Arten (Weißbart-Grasmücke und Zilpzalp) zeigten eine positive Fettdepositionsrate, wahrscheinlich aufgrund der besseren Eignung des Lebensraums der Insel für diese beiden Arten. Die intensive Nutzung der Insel trotz der relativ geringen Auftankmöglichkeiten, könnte auf andere Aspekte zurückzuführen sein, die die Insel den Vögeln anbietet. Möglicherweise benötigen Vögel, die gerade nach einer langen Meeresüberquerung gelandet sind, eine kurze

Communicated by N. Chernetsov.

Electronic supplementary material The online version of this article (https://doi.org/10.1007/s10336-020-01768-7) contains supplementary material, which is available to authorized users.

Ivan Maggini

ivan.maggini@vetmeduni.ac.at

1 Austrian Ornithological Centre, Konrad-Lorenz Institute of Ethology, University of Veterinary Medicine Vienna, Savoyenstrasse 1a, 1160 Wien, Austria
2 Department of Aquatic Resources, Institute of Marine Research, Swedish University of Agricultural Sciences, Turistgatan 5, 45330 Lysekil, Sweden

3 Department of Cognitive Biology, University of Vienna, Althanstrasse 14, 1090 Vienna, Austria 
Rast oder Schlaf und finden auf diesen Inseln Gelegenheiten dafür. Diese Vögel würden im Normalfall nach wenigen Stunden weiterfliegen. Das Verständnis der Rolle dieser Inseln für Zugvögel ist daher auch für deren Schutz wichtig, da die Festlegung von Schutzmaßnahmen unvollständig ist, wenn nur der Erfolg des Auftankens als wichtige Variable betrachtet wird.

\section{Introduction}

Migratory birds often face ecological barriers during their seasonal movements, such as deserts, mountain ranges, and very often water bodies. Many songbirds are nocturnal migrants, but they are forced to extend their travel time when crossing very large water bodies (Grattarola et al. 1999; Deppe et al. 2015; Adamík et al. 2016). This may lead to fatigue and depletion of energy reserves and require a stopover at the end of the crossing. Small islands close to the coast offer the first possibility for landing, and indeed attract large numbers of migratory birds (Moore et al. 1990; Spina et al. 1993). Researchers have taken advantage of the accumulation of birds to study stopover strategies in these islands. Two notable examples are the small islands in the Northern Gulf of Mexico and those in the Mediterranean Sea, both during northward spring migration (Moore et al. 1990; Spina et al. 1993).

An interesting fact about these islands is that usually they attract birds of a wide range of species, often irrespective of their usual habitat requirements (Moore et al. 1990; Spina et al. 1993). This is somehow surprising, because habitat quality has been identified as the major factor affecting stopover success (McCabe and Olsen 2015). In particular, food availability seems to be the most important driver of stopover duration (Buler et al. 2017). Therefore, because of these factors and due to the high competition arising from sharing the site with large numbers of migrants, birds of many species may limit the duration of their stay on the island and relocate to more favorable coastal sites for refueling after a short rest. Indeed, studies in the Gulf of Mexico showed that birds are more commonly found in favourable forest habitats (Lester et al. 2016) and that stopover strategies are different among species (Morris et al. 1994; Yong and Moore 1997). If the islands offer refueling possibilities, they are used more extensively, though the extent of refueling might differ among species depending on their habitat requirements (Morris et al. 2003; Suomala et al. 2012).

The lack of refueling opportunities on islands might force many birds to relocate to more favourable sites on the mainland (Schmaljohann and Eikenaar 2017), where a more varied offer of habitats is available. Stopover duration is influenced by the distance to the next available sites (Schaub et al. 2008), and islands that attract large numbers of birds are often located not far from the coast (Moore et al. 1990; Spina et al. 1993). Therefore, it is not surprising that relocation to the coast is the most common pattern found in many species (Kuenzi et al. 1991; Moore and Aborn 1996) and more extensive refueling at the coast or at inland sites has been confirmed (Moore and Kerlinger 1987; Buler and Moore 2011).

It seems, however, that small islands might represent an important staging alternative under particular conditions. In some cases, birds might be particularly depleted of energy stores, so that they are not able to continue their flight. In this situation, birds might try to refuel, at least to gather enough energy to reach better sites on the mainland. Lean birds spend longer time on these islands (Goymann et al. 2010) and are sometimes able to increase their body mass (Tenan and Spina 2010), especially when they experience positive fuel deposition rates (Moore et al. 2017). Studies that kept birds in short-term captivity showed that birds decrease their nocturnal migratory restlessness for some days when in poor condition (Yong and Moore 1993; Fusani et al. 2009). Even if not in a particularly bad condition, birds might need a short rest after the intense exercise of sea crossing (Schwilch et al. 2002; Ferretti et al. 2019a). Islands may provide a safer environment for resting since predation pressure is generally lower than on the mainland (Cooper et al. 2014). When addressing the importance of small islands for migrants, it is important to understand whether they are used as a last resort or simply as a safe environment for resting.

We studied stopover dynamics on the island of Ponza (Italy). Here, short-term captive studies have shown that birds have a lower intensity of migratory restlessness when in poor conditions (Fusani et al. 2009), and a whole-island telemetry study in the neighbor island of Ventotene has confirmed that this is reflected in a longer stopover duration in nature (Goymann et al. 2010). The migratory disposition of birds doing a stopover on these islands, however, is sensible to the availability of food (Lupi et al. 2017) in a manner that varies among species and depends on food quantity (Ferretti et al. 2019a). The results of short-term captive studies suggest that birds arriving on Ponza have the disposition to refuel when their energy stores are low, but require sufficient amounts of food to induce a quick departure. There are no data on food availability and on refueling rates in free-flying birds on Ponza yet. However, a large dataset of ringing data with within-season recaptures is available. We used this dataset to estimate stopover dynamics in $12 \mathrm{com}$ mon species to assess the role of the island of Ponza for migratory birds during spring migration. We distinguished between three scenarios: 
(a) The island is used for refueling by birds in low body condition.

(b) The island is used for opportunistic foraging, but not for extensive refueling.

(c) The island is not used for refueling and birds landing on Ponza do so mostly for short-term resting after a long non-stop flight.

The scenarios are not mutually exclusive, and might depend on body condition of the birds and differ among species. If (a) was true, we predicted a high proportion of long stopovers (two or more days) in birds with low body condition (as indicated by their body mass), and an increase in body mass over time. A high proportion of recaptures within a short time scale (one day or less), and an increase in body mass within one day from recapture would support scenario (b). For scenario (c), we predicted a low percentage of recaptures and no increase in body mass, neither in the short nor in the long term.

\section{Methods}

This study was conducted on the island of Ponza, central Italy $\left(40^{\circ} 55^{\prime} \mathrm{N}, 12^{\circ} 58^{\prime} \mathrm{E}\right)$. A ringing station (www.inane llamentoponza.it) operates here throughout the spring season, usually from the beginning of March to mid-May. The data presented in this study were obtained during the spring seasons of 2014 (30 March to 17 May), 2015 (12 March to 22 May) and 2016 (13 March to 20 May). Birds were captured with $340 \mathrm{~m}$ of mist-nets that were controlled every hour from sunrise to sunset every day, except for days with rain or strong winds. After being captured, birds were ringed and measured using standard procedures (Bairlein 1995). We measured the length of the eighth primary using a pin ruler with a precision of $\pm 0.5 \mathrm{~mm}$, and body mass with an electronic scale with a precision of $\pm 0.1 \mathrm{~g}$. Immediately after weighing, the birds were released. Every time a ringed bird was recaptured, we recorded its body mass again and immediately released it. We calculated a condition index at first capture using the scaled mass index (SMI, Peig and Green 2009). The formula used for SMI was $\mathrm{SMI}=M_{\mathrm{i}} \times\left(\mathrm{P}_{0} / \mathrm{P}_{\mathrm{i}}\right)^{\mathrm{b}_{\mathrm{SMA}}}$, where $\mathrm{M}_{\mathrm{i}}$ and $\mathrm{P} 8_{\mathrm{i}}$ were the body mass and the length of the eigth primary of any given individual, $\mathrm{P} 8_{0}$ was the average length of the eighth primary of the species (calculated from the whole sample of three years of data), and $b_{\text {SMA }}$ was the scaling exponent calculated from the standardized major axis of the regression of body mass on eigth primary length. Recapture data were collected in all species, and more in-depth analysis was performed on the most commonly recaptured species.

Data presented here were obtained on 46,230 birds belonging to 12 species with more than 1000 individuals captured over the 3 years of the study (Barn Swallow Hirundo rustica was excluded despite the number of captures was 1228 because it had very low recapture rates, see Table S1). Descriptive statistics for the other species are given in the supplementary materials (Table S1). We performed in-depth analysis of the following species: Common Chiffchaff Phylloscopus collybita (hereafter Chiffchaff), Common Redstart Phoenicurus phoenicurus (hereafter Redstart), European Robin Erithacus rubecula (hereafter Robin), Garden Warbler Sylvia borin, Common Whitethroat Sylvia communis (hereafter Whitethroat), Icterine Warbler Hippolais icterina, European Pied Flycatcher Ficedula hypoleuca (hereafter Pied Flycatcher), Spotted Flycatcher Muscicapa striata, Subalpine Warbler Sylvia cantillans, Whinchat Saxicola rubetra, Willow Warbler Phylloscopus trochilus, and Wood Warbler Phylloscopus sibilatrix.

The birds were assigned to one of four groups depending on the occurrence of recaptures. In case of multiple recaptures, only data from the first and last capture were considered. Birds were included in the "no recapture" group if they were captured only once; the "same day" group included birds that were recaptured on the same day as the first capture; the "one day stopover" group was formed by birds recaptured on the day following first capture; and the "long stopover" group contained birds recaptured after more than one day from first capture. Recaptures within $3 \mathrm{~h}$ from first capture were not considered, as they might have included birds flying directly into the net after release. These birds were included in the "no recapture" group. Including them in the analysis as "same day" birds did not change the outcome of the analyses.

We analyzed differences among species in Julian date of passage, time of capture, and fat scores using Kruskal-Wallis one-way analysis of variance. We used non-parametric statistics because they are based on non-linear variables (fat score) or on skewed data (time of capture). Julian date could fit a parametric statistic, but we preferred to use the same test as for the other variables. This analysis was simply used to describe broadly the differences across species and we did not need high statistical power for this. We did not perform post hoc analyses because pairwise comparisons between species were not meaningful for the scope of this study.

We analyzed differences among the four groups in SMI at first capture, time of day and Julian date (i.e. days passed after 1 January) using random intercept mixed effects linear models including group as a fixed factor, and species and year as random factors. If a significant difference between groups was found, we performed pairwise comparisons using the glht function with Tukey corrections from the multcomp package in R 2.14.0 (Hothorn et al. 2008). This analysis served to give a general view excluding effects due to different ecology of the species. To investigate speciesspecific patterns, we then analyzed differences in SMI, time 
of day (at first capture) and Julian date at first capture in all species separately using one-way ANOVAs. In case of a significant result $(p<0.05)$, we conducted pairwise $t$ tests with Bonferroni corrections as a post hoc test.

In the "long stopover" group, we estimated the minimum stopover duration by the number of days passed after capture. To estimate fuel deposition rate, we were not able to use Cormack-Jolly-Seber models because of the very large proportion of transients in our dataset. For an estimate of fuel deposition, we modelled the change in body mass (body mass at recapture-body mass at first capture) as a function of minimum stopover duration and the difference in time of day as a covariate, since body mass increases during the day but decreases again during the night, so that the net body mass gain must be estimated accounting for this (Schaub et al. 2008). For this regression, the intercept was set to 0 (Schaub and Jenni 2000). We used the average of the predicted values of this model as a measure of fuel deposition rate (in $\mathrm{g} /$ day) for each species. This analysis was not performed in species with $\leq 10$ individuals in the "long
Table 2 Results of mixed effects linear models to test for differences among groups in time of first capture, date of passage, and SMI

\begin{tabular}{lccl}
\hline Group & Estimate $\pm \mathrm{SE}$ & $t$ value & $p$ \\
\hline Fixed factor: time of first capture (time of day) & & \\
Transient & $12.2 \pm 0.1$ & 21.24 & $<0.001$ \\
Same day & $11.0 \pm 0.2$ & 21.24 & $<0.001$ \\
One day & $15.4 \pm 0.4$ & 39.67 & $<0.001$ \\
Long stopover & $12.9 \pm 0.2$ & 10.34 & $<0.001$
\end{tabular}

Fixed factor: date of first capture (Julian date-Day $1=1$ January)

\begin{tabular}{|c|c|c|c|}
\hline Transient & $111.8 \pm 0.4$ & 1.35 & 0.179 \\
\hline Same day & $111.7 \pm 0.5$ & 0.79 & 0.431 \\
\hline One day & $111.3 \pm 4.6$ & 23.95 & $<0.001$ \\
\hline Long stopover & $109.1 \pm 0.6$ & 3.70 & $<0.001$ \\
\hline \multicolumn{4}{|c|}{ Fixed factor: Scaled Mass Index (SMI) (g) } \\
\hline Transient & $12.1 \pm 0.1$ & 5.84 & $<0.001$ \\
\hline Same day & $11.9 \pm 0.1$ & 2.01 & 0.045 \\
\hline One day & $11.7 \pm 0.9$ & 13.41 & $<0.001$ \\
\hline Long stopover & $11.6 \pm 0.1$ & 0.67 & 0.501 \\
\hline
\end{tabular}

Species and year were entered as random factors

Table 1 Species details about the distribution in the four groups "no recapture", "same day recapture", "one day stopover", "long stopover" for the 12 species analyzed

\begin{tabular}{|c|c|c|c|c|c|c|c|c|}
\hline Species & $N$ & $\begin{array}{l}N \text { no recapture } \\
(\%)\end{array}$ & $N$ same day (\%) & One day $(\%)$ & $\begin{array}{l}\text { Long stopover } \\
(\%)\end{array}$ & $\begin{array}{l}\text { Median date } \\
\text { of passage [IQ } \\
\text { range] }\end{array}$ & $\begin{array}{l}\text { Median time } \\
\text { of capture [IQ } \\
\text { range] }\end{array}$ & $\begin{array}{l}\text { Median fat } \\
\text { score [IQ } \\
\text { range] }\end{array}$ \\
\hline Chiffchaff & 1165 & 1107 (95.0) & $21(1.8)$ & $11(0.9)$ & $26(2)$ & 86 [77-96] & $\begin{array}{l}\text { 10:00 [08:00- } \\
13: 00]\end{array}$ & $2[0-4]$ \\
\hline Garden Warbler & 11,953 & $11,577(96.9)$ & $170(1.4)$ & $125(1.0)$ & $81(0.7)$ & 127 [124-131] & $\begin{array}{l}\text { 11:00 [09:00- } \\
13: 00]\end{array}$ & $1[0-2]$ \\
\hline Icterine Warbler & 5359 & 5237 (97.7) & $76(1.4)$ & $38(0.7)$ & $8(0.1)$ & 130 [127-132] & $\begin{array}{l}\text { 11:00 [08:00- } \\
15: 00]\end{array}$ & $2[1-3]$ \\
\hline Pied Flycatcher & 2280 & $2181(95.7)$ & $22(1.0)$ & $56(2.5)$ & $21(0.9)$ & $114[108-121]$ & $\begin{array}{l}14: 00[10: 00- \\
17: 00]\end{array}$ & $1[0-2]$ \\
\hline Redstart & 1343 & $1301(96.9)$ & $20(1.5)$ & $12(0.9)$ & $10(0.7)$ & 102 [95-116] & $\begin{array}{l}12: 00[09: 00- \\
15: 00]\end{array}$ & $2[0-3]$ \\
\hline Robin & 3996 & 3709 (92.8) & $81(2.0)$ & $148(3.7)$ & $58(1.5)$ & 81 [78-87] & $\begin{array}{l}\text { 14:00 [09:00- } \\
18: 00]\end{array}$ & $2[0-3]$ \\
\hline $\begin{array}{l}\text { Spotted Fly- } \\
\text { catcher }\end{array}$ & 1838 & $1802(98.0)$ & $11(0.6)$ & $22(1.2)$ & $3(0.2)$ & 128 [125-135] & $\begin{array}{l}15: 00[12: 00- \\
18: 00]\end{array}$ & $1[0-2]$ \\
\hline $\begin{array}{r}\text { Subalpine } \\
\text { Warbler }\end{array}$ & 2561 & $2402(93.8)$ & $57(2.2)$ & $44(1.7)$ & $58(2.3)$ & 96 [88-101] & $\begin{array}{l}\text { 11:00 [08:00- } \\
13: 00]\end{array}$ & $2[1-4]$ \\
\hline Whinchat & 2353 & 2277 (96.8) & $39(1.7)$ & $31(1.3)$ & $6(0.3)$ & 122 [111-127] & $\begin{array}{l}13: 00[10: 00- \\
17: 00]\end{array}$ & $2[0-3]$ \\
\hline Whitethroat & 6804 & 6554 (96.3) & $98(1.4)$ & $89(1.3)$ & $63(0.9)$ & 121 [115-127] & $\begin{array}{l}\text { 10:00 [08:00- } \\
13: 00]\end{array}$ & 3 [1-4] \\
\hline Willow Warbler & 2971 & 2865 (96.4) & $56(1.9)$ & $29(1.0)$ & $21(0.7)$ & 101 [92-114] & $\begin{array}{l}\text { 11:00 [09:00- } \\
14: 00]\end{array}$ & $3[2-4]$ \\
\hline Wood Warbler & 3607 & 3443 (95.5) & $59(1.6)$ & $57(1.6)$ & $48(1.3)$ & 113 [108-123] & $\begin{array}{l}\text { 13:00 [09:00- } \\
17: 00]\end{array}$ & 0 [0-2] \\
\hline
\end{tabular}

Data refer to captures on Ponza Island during spring migration between 2014 and 2016. Median date of passage, time of capture, and fat score (after Kaiser 1993) are based on first capture, and are given with the interquartile range 
stopover" group (i.e. Redstart, Icterine Warbler, Spotted Flycatcher, and Whinchat).

To determine whether birds opportunistically refuel during when spending just a short time on the island, we considered birds from the "same day" group. For these birds we constructed a linear correlation between the change in body mass and the time passed between the two capture events (in hours), setting the intercept to 0 . The slope of the correlation was indicative of hourly body mass change. All analyses were performed using R 3.6.1 (R Core Team 2019).

\section{Results}

When grouping "no recapture" and "same day" birds to describe birds that performed no stopover on Ponza (duration of stay did not extend to the next day), the highest proportion of no-stopovers was in the Icterine Warbler (99.1\%). In all species, no-stopovers were more than $95 \%$ of the individuals, except for the Robin where the proportion was $94.8 \%$. Data are summarized in Table 1 . The 12 study species differed in date of passage $(\chi=28,226, d f=11, p<0.001)$, time of first capture $(\chi=2988.1, d f=11, p<0.001)$, and fat score at first capture $(\chi=5074.2, d f=11, p<0.001)$.

When pooling all species and controlling for species and year, we found significant differences among groups in time of capture (LMM: $F_{3,46211}=179.3, p<0.001$; Table 2). Same day recaptures were captured the earliest, followed by long stopover birds, "no recapture" birds, and one day recaptures (all pairwise comparisons $\leq 0.001$, Table 2 ). Julian date of first capture also differed among groups $\left(F_{3,46213}=11.4, p<0.001\right.$, Table 2$)$. Long stopover birds were first caught on average earlier than birds from the other three groups (all three pairwise comparisons $p<0.001$, Table 2), while the other three groups did not differ in their average capture date (all pairwise comparisons $p>0.5$ ). SMI at first capture differed among groups $\left(F_{3,45796}=23.9\right.$, $p<0.001$, Table 2). "No recapture" birds had the highest values of SMI, significantly higher than the other three groups (no recapture vs. same day $p=0.007$, no recapture vs. one day/long stopover $p<0.001$ ). The differences between the other groups were not significant (same day vs. one day $p=0.172$, long stopover vs. one day $p=0.898$, long stopover vs. same day $p=0.067)$. The lowest SMI was in the long stopover group (Table 2).

Chiffchaff The four groups did not differ in their date of passage $\left(F_{3,1161}=0.550, p=0.648\right)$, initial capture time $\left(F_{3,1161}=1.764, p=0.152\right.$, Fig. 1$)$, or SMI at first capture $\left(F_{3,1140}=1.600, p=0.188\right.$, Fig. 2$)$. Long stopover birds had a non-significant positive fuel deposition rate $(0.11 \pm 0.22$ $\mathrm{g} /$ day, $t=0.858, p=0.400$ ). Same day recaptures did not
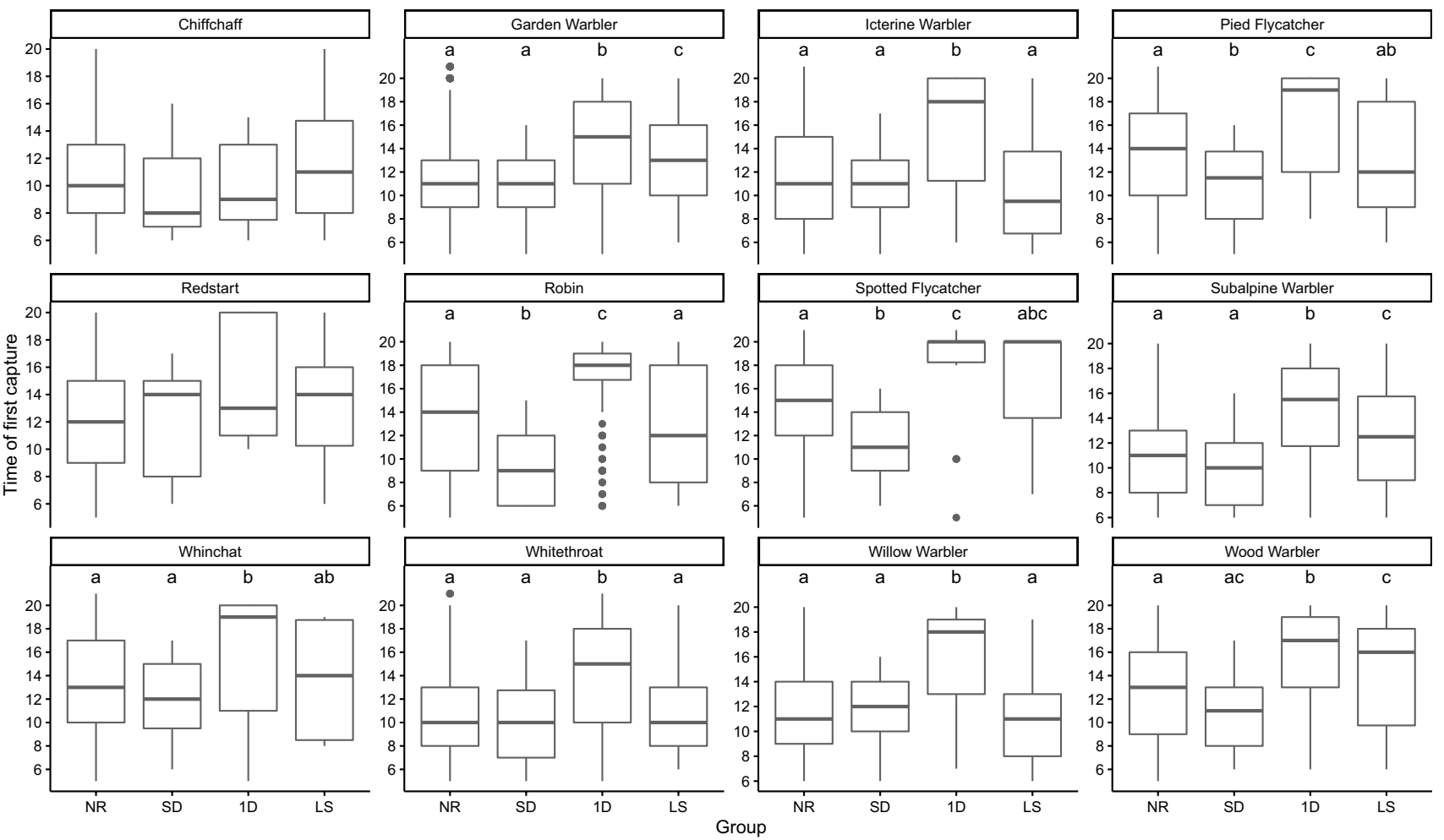

Fig. 1 Scaled Mass Index at first capture in the four groups "no recapture" (NR), "same day recapture" (SD), "one day stopover" (1D), "long stopover" (LS) for the 12 species analyzed. Letters above the boxplots indicate significant differences 

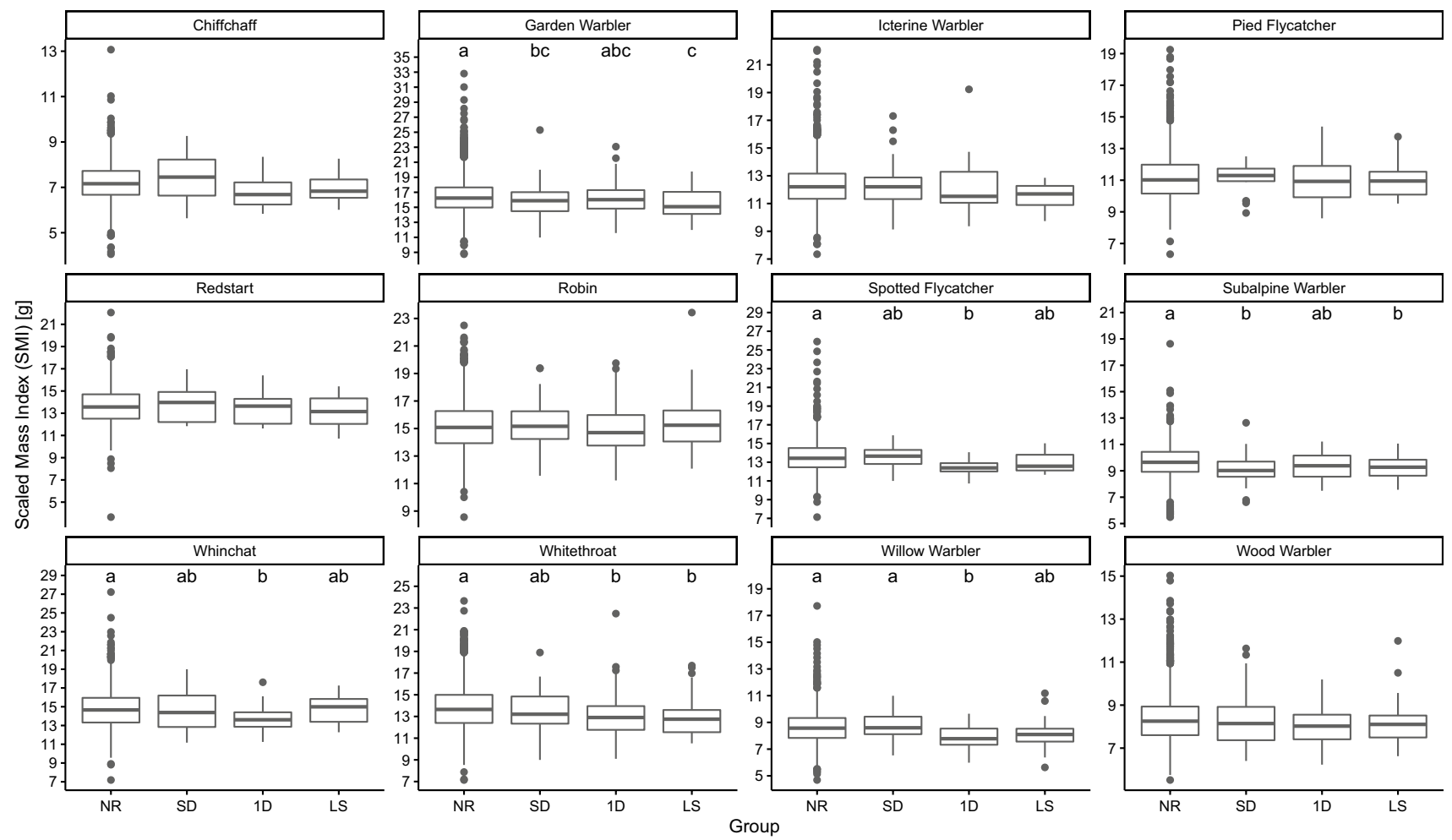

Fig. 2 Time of first capture in the four groups "no recapture" (NR), "same day recapture" (SD), "one day stopover" (1D), "long stopover" (LS) for the 12 species analyzed. Letters above the boxplots indicate significant differences

significantly change their body mass $(0.00 \pm 0.01 \mathrm{~g} / \mathrm{h}, t=$ $-0.193, p=0.849$ ).

Garden Warbler The four groups did not differ in their date of passage $\left(F_{3,11949}=1.657, p=0.174\right)$. Initial capture time was different among groups $\left(F_{3,11949}=58.300, p<0.001\right.$, Fig. 1). One day recaptures were trapped significantly later than "no recapture" birds, same day recaptures (both $p<0.001)$ and long stopover birds $(p=0.006)$. Long stopover birds were captured later than "no recapture" birds and same day recaptures (both $p<0.001$ ). There was a difference in SMI at first capture between groups $\left(F_{3,11865}=10.580\right.$, $p<0.001$, Fig. 2). "No recapture" birds were heavier than same day recaptures $(p=0.004$ and long stopover birds $(p<0.001)$. Long stopover birds had a non-significant negative fuel deposition rate $(-0.01 \pm 0.12 \mathrm{~g} / \mathrm{day}, t=0.127$, $\mathrm{i}=0.900)$. Same day recaptures had a significant negative change in body mass $(-0.05 \pm 0.01 \mathrm{~g} / \mathrm{h}, t=-5.091$, $p<0.001)$.

Icterine Warbler There was a significant difference among groups in date of passage $\left(F_{3,5355}=4.174, p=0.006\right)$. Post hoc tests, however, did not confirm any difference between groups (all $p>0.05$ ). Initial capture time was different among groups $\left(F_{3,5355}=10.300, p<0.001\right.$, Fig. 1). One day recaptures were trapped significantly later than "no recapture" birds, same day recaptures (both $p<0.001$ ) and long stopover birds $(p=0.028)$. SMI, at first capture, did not differ among groups $\left(\mathrm{F}_{3,5307}=1.229, p=0.298\right.$, Fig. 2$)$. Same day recaptures did not significantly change their body mass $(-0.03 \pm 0.03 \mathrm{~g} / \mathrm{h}, t=-1.349, p=0.181)$.

Pied Flycatcher The four groups did not differ in their date of passage $\left(F_{3,2276}=1.251, p=0.290\right)$ or Initial capture time was different among groups $\left(F_{3,2276}=12.130\right.$, $p<0.001$, Fig. 1). One day recaptures were trapped significantly later than "no recapture" birds, same-day recaptures (both $p<0.001)$, and long stopover birds $(p=0.019)$. Same day recaptures were initially captured earlier than "no recapture" birds $(p=0.014)$. There were no differences in initial SMI among the four groups $\left(F_{3,2256}=0.175\right.$, $p=0.913$, Fig. 2). Long stopover birds had a non-significant positive fuel deposition rate $(0.41 \pm 0.67 \mathrm{~g} /$ day, $t=0.643, p=0.528)$. Same day recaptures significantly lost body mass over time $(-0.04 \pm 0.01 \mathrm{~g} / \mathrm{h}, t=-4.014$, $p<0.001)$.

Redstart The four groups did not differ in their date of passage $\left(F_{3,1339}=0.443, p=0.722\right)$, initial capture time $\left(F_{3,1339}=2.148, p=0.092\right.$, Fig. 1$)$, or initial SMI $\left(F_{3,1328}=0.479, p=0.697\right.$, Fig. 2$)$ and same day recaptures 
did not significantly change their body mass $(-0.04 \pm 0.04$ $\mathrm{g} / \mathrm{h}, t=-1.113, p=0.279)$.

Robin Julian date of first capture differed among groups $\left(F_{3,3992}=3.664, p=0.012\right)$. Post hoc tests revealed birds in the one day stopover group occurred slightly later in the season $(p=0.034)$. Initial capture time was different among groups $\left(F_{3,3992}=41.180, p<0.001\right.$, Fig. 1$)$. One day recaptures were trapped significantly later than "no recapture" birds, same day recaptures, and long stopover birds (all $p<0.001$ ). Same day recaptures were captured earlier than "no recapture" birds and long stopover birds (both $p<0.001$ ). Initial SMI did not differ among groups $\left(F_{3,3966}=0.775, p=0.508\right.$, Fig. 2). Long stopover birds had a non-significant negative fuel deposition rate $(-0.06 \pm 0.16$ $\mathrm{g} /$ day, $t=-1.476, p=0.146)$. Same-day recaptures significantly lost body mass over time $(-0.03 \pm 0.01 \mathrm{~g} / \mathrm{h}, t=$ $-2.968, p=0.004)$.

Spotted Flycatcher The four groups did not differ in their date of passage $\left(F_{3,1834}=1.338, p=0.260\right)$. Initial capture time was different among groups $\left(F_{3,1834}=7.297, p<0.001\right.$, Fig. 1). One day recaptures were trapped significantly later than "no recapture" birds and same day recaptures (both $p<0.001)$. Same day recaptures were initially captured earlier than "no recapture" birds $(p=0.044)$. Birds of the four groups differed in initial SMI $\left(F_{3,1817}=3.256, p=0.021\right.$, Fig. 2). "No recapture" birds were heavier than one day recaptures $(p=0.012)$. Same day recaptures did not significantly change their body mass $(-0.02 \pm 0.01 \mathrm{~g} / \mathrm{h}, t=$ $-1.665, p=0.127$ ).

Subalpine Warbler The four groups did not differ in their date of passage $\left(F_{3,2557}=0.517, p=0.671\right)$. Initial capture time was different among groups $\left(F_{3,2557}=21.780, p<0.001\right.$, Fig. 1). One day recaptures were trapped significantly later than "no recapture" birds, same day recaptures (both $p<0.001)$, and long stopover birds $(p=0.007)$. "No recapture" birds $(p=0.008)$ and same day recaptures $(p<0.001)$ were initially captured earlier than long stopover birds. Birds of the four groups differed in initial SMI $\left(F_{3,2526}=8.272\right.$, $p<0.001$, Fig. 2). "No recapture" birds were heavier than long stopover birds $(p=0.021)$ and same day recaptures $(p=0.003)$. Long stopover birds had a significant positive fuel deposition rate $(0.27 \pm 0.31 \mathrm{~g} /$ day, $t=3.844, p<0.001)$. Same day recaptures did not significantly change their body mass $(0.02 \pm 0.02 \mathrm{~g} / \mathrm{h}, t=1.205, p=0.233)$.

Whinchat The groups differed in their date of passage $\left(F_{3,2349}=3.216, p=0.022\right)$. The birds in the "long stopover" group occurred on average earlier than "no recapture" birds $(p=0.049)$. Initial capture time was different among groups $\left(F_{3,2349}=5.799, p<0.001\right.$, Fig. 1$)$. One day recaptures were trapped significantly later than "no recapture" birds $(p=0.001)$ and same day recaptures $(p<0.001)$. There were significant differences in initial SMI among the four groups $\left(F_{3,2325}=2.825, p=0.037\right.$, Fig. 2$)$. "No recapture" birds were heavier than one day recaptures $(p=0.024)$. Same day recaptures significantly lost body mass over time $(-0.05 \pm 0.02$ $\mathrm{g} / \mathrm{h}, t=-2.246, p=0.031$ ).

Whitethroat The groups differed in their date of passage $\left(F_{3,6800}=5.529, p<0.001\right)$. The birds in the "long stopover" group occurred on average earlier than the other groups (long stopover-no recapture: $p=0.001$; long stopover-same day: $p<0.001$; long stopover-one day: $p=0.010$ ). Initial capture time was different among groups $\left(F_{3,6800}=26.920\right.$, $p<0.001$, Fig. 1). One day recaptures were trapped significantly later than"no recapture" birds, same day recaptures, and long stopover birds (all $p<0.001$ ). Birds of the four groups differed in initial SMI $\left(F_{3,6730}=6.954, p<0.001\right.$, Fig. 2). "No recapture" birds were heavier than one day recaptures $(p=0.007)$ and long stopover birds $(p=0.017)$. Long stopover birds had a non-significant positive fuel deposition rate $(0.05 \pm 0.01 \mathrm{~g} / \mathrm{day}, t=1.978, p=0.053)$. Same day recaptures significantly lost body mass over time $(-0.05 \pm 0.01 \mathrm{~g} / \mathrm{h}, t=-5.042, p<0.001)$.

Willow Warbler There was a significant difference among groups in the date of passage $\left(F_{3,2967}=2.823, p=0.037\right)$. Post hoc tests, however, did not confirm any difference between groups (all $p>0.10$ ). Initial capture time was different among groups $\left(F_{3,2967}=12.040, p<0.001\right.$, Fig. 1$)$. One day recaptures were trapped significantly later than "no recapture" birds, same day recaptures, and long stopover birds (all $p<0.001)$. Birds of the four groups differed in initial SMI $\left(F_{3,2925}=4.877\right.$, $p=0.002$, Fig. 2). "No recapture" birds $(p=0.008)$ and same day recaptures $(p=0.027)$ were heavier than one day stopover birds. Long stopover birds had a non-significant positive fuel deposition rate $(0.23 \pm 0.23 \mathrm{~g} / \mathrm{day}, t=1.189, p=0.249)$. Same day recaptures did not significantly change their body mass $(-0.02 \pm 0.01 \mathrm{~g} / \mathrm{h}, t=-1.609, p=0.113)$.

Wood Warbler The four groups did not differ in their date of passage $\left(F_{3,3603}=2.111, p=0.097\right)$. Initial capture time was different among groups $\left(F_{3,3603}=15.470, p<0.001\right.$, Fig. 1). One day recaptures were trapped significantly later than "no recapture" birds and same day recaptures (both $p<0.001)$. Long stopover birds were initially captured later than "no recapture" birds $(p=0.002)$ and same day recaptures $(p<0.001)$. There were no differences in initial SMI among the four groups $\left(F_{3,3580}=2.332, p=0.072\right.$, Fig. 2$)$. Long stopover birds had a non-significant negative fuel deposition rate $(-0.21 \pm 0.18 \mathrm{~g} / \mathrm{day}, t=-0.985, p=0.330)$. Same day recaptures significantly lost body mass over time $(-0.05 \pm 0.01 \mathrm{~g} / \mathrm{h}, t=-3.114, p=0.003)$. 


\section{Discussion}

The island of Ponza, similar to other Mediterranean islands, attracts large numbers of migrants throughout the spring. This study shows that the island is not extensively used for prolonged refueling stopovers by most species unless the birds are in a critically low condition. In 5 out of 12 species considered in this study, birds that stayed for longer than one day had a body mass below the average of their species. However, only 1 of 12 species, the Subalpine Warbler, was able to increase its body mass significantly over the duration of the stopover. In 6 of 12 species, there was a decrease in body mass over the first day of stopover. This indicates that the island offers little opportunities to refuel, or that refueling is not the main reason for birds to land on this island. After a sea crossing of about $500 \mathrm{~km}$, low refueling rates might be indicative of a reduced digestive tract (Piersma and Lindström 1997; Bauchinger et al. 2005), thus foraging might not be the priority for birds landed on Ponza. Recovery after a long endurance flight might require at first resting and sleeping (Schwilch et al. 2002; Nemeth 2009; Ferretti et al 2019a). Habitat cover is a determinant of refueling stopover (Ktitorov et al. 2008), and if the island does not provide appropriate habitat to birds of a given species, these are expected to leave without refueling after a short rest. Some islands may provide opportunistic foraging options in the form of nectar (Schwilch et al. 2001; Cecere et al. 2010, 2011). Ponza does not seem to offer such opportunities to the birds, which might explain why birds on long stopovers are not refueling as successfully as on the neighboring island of Ventotene (Tenan and Spina 2010). Despite the presence of insects and berries on the island, birds do not seem to use them extensively in an opportunistic manner. Maybe this behaviour is restricted to some individuals that choose refueling over resting, but this is not reflected by the overall patterns for each species.

Only two species had a proportion of more than $2 \%$ of birds in the "long stopover" group, indicative of a decision to stay on the island with the purpose of refueling: Chiffchaff and Subalpine Warbler. Both species have small breeding populations on Ponza or on islands with similar habitat in the Tyrrhenian Sea (Meschini and Frugis 1993). We do not think that the estimated stopover length we report for these species was affected by captures of resident birds, given the large numbers of individuals captured for both species. Much rather, their tendency of using the stopover site for a longer time might reflect a better adaptation to the island's habitat. Subalpine Warblers were the only species showing a positive fuel deposition rate when staying for longer than one day, and the fuel deposition rate was positive in Chiffchaffs as well, though not significantly so. These data support the idea that small islands can provide good refueling opportunities to certain species if the habitat is suitable
(Morris et al. 2003; Suomala et al. 2012). Why other species with similar habitat requirements and diets (e.g. Willow Warblers) did not seem to have the same ability to use the site is not clear, but might be related to fine niche differences that we are not able to detect.

Birds captured later in the day were more likely to be recaptured on the following day on Ponza. Our interpretation of this observation is that departure is dependent on the time of arrival for birds that are using the island primarily for resting, i.e. a bird would need some time to recover from fatigue and sleep deprivation. Late arrivals might not have enough time to recover before sunset, which is the time they usually depart (Goymann et al. 2010). Unfortunately, we do not have data to show that birds captured later in the day coincide with later arrivals on Ponza. In any case, it is questionable whether one day stopovers should be regarded as true refueling stopovers. The two species with the highest proportion of birds in the "one day stopover" group were the Robin and the Pied Flycatcher. These were two of the species with the latest mean capture time overall (the only species with an even later time of capture being the Spotted Flycatcher). The percentage of long stopovers in these species was relatively low, though. Therefore, there is no evidence suggesting that these two species have an overall different stopover strategy compared to the other species. Much rather, their presence on the island on the day following capture may be a result of their overall tendency to arrive later.

In general, data collected on Ponza are not dissimilar from those of other Mediterranean islands. The rate of recaptured birds is even lower than that of most Western Mediterranean islands with the exception of Columbretes in Spain (Gargallo et al. 2011). Similar to Ponza, these are relatively small islands that birds encounter after a long sea crossing and offer limited refueling opportunities. However, the number of captures on Columbretes is rather high, considering the small number of mistnets used (Gargallo et al. 2011). Therefore, it seems likely that isolated small islands following a long sea crossing have the same function for migratory birds irrespective of the flyway used. Fat stores of birds landing on the small islands off the Italian coast are usually sufficient for the further short flight to reach the mainland (Pilastro and Spina 1997), where more optimal habitat patches are available. Together with our data, this suggests that foraging is not the primary aim when landing on these islands. Therefore, the question arises why such large numbers of birds would land on the islands at all. There is strong evidence that birds continue their migration over the Mediterranean Sea during the early daylight hours (Grattarola et al. 1999; Messineo et al. 2001), providing little support to the idea that birds would land on the islands to interrupt diurnal flight. The generally poorer condition of birds captured on the islands compared to birds captured 
at mainland sites (Gargallo et al. 2011) might be simply the result of the long sea crossing preceding capture, which requires large amounts of energy and therefore leads to a rapid depletion of fat stores (Gargallo et al. 2011).

Islands with low refueling resources, however, should not be considered as "last resorts" for birds in poor conditions. Stopover sites can have different functions for birds depending on their location and availability of habitat. Mehlman et al. (2005) divided stopover habitats into three different categories. Small islands close to the coast and with little suitable habitat available, attracting large numbers of individuals, with numbers mostly depending on weather, fit into the "fire escape" category. According to Mehlman et al. (2005), stopover sites in this category should attract large numbers of birds only during adverse weather events and provide life-saving opportunities to land. On Tyrrhenian islands, capture numbers are predicted by wind and temperature both on site and at departure from Northern Africa (Saino et al. 2010). However, this is not related to adverse weather, since the largest numbers of birds on Ponza are captured during stable weather conditions (pers. obs.). Thus, if and how these islands provide life-saving services to the birds remain to be assessed, considered that refueling options are not optimal. Probably, birds needing a simple rest would choose islands over the mainland because of the lower predation risk (Cooper et al. 2014).

The results of this study are not only relevant for the island of Ponza, and much rather should reflect the needs of birds after a long endurance flight. Therefore, the results obtained here can reasonably be extrapolated to other situations along the migratory route. Conservation of migratory birds should address all stages of their life history (Mehlman et al. 2005; Martin et al. 2007; Buler and Moore 2011). Stopover sites have received less attention than breeding and wintering areas, probably as a result of their ephemeral nature. Nonetheless, large numbers of birds are present at some sites despite the lack of optimal refueling options, indicating that refueling is not the only resource that a stopover site should offer. For conservation, this implies that assessing quality of sites only by observing fuel deposition rates might provide incomplete information and be misleading. Future studies should focus on alternative use of small islands and how this can affect the success of migration for thousands of birds that are consistently present on these islands through the years.

Acknowledgments Open access funding provided by University of Veterinary Medicine Vienna. We are thankful to the many ringers and volunteers that helped with bird capture and data collection on Ponza during the 3 years of the study. We thank one anonymous reviewer for comments on an earlier version of this manuscript. This is publication N. XX68 of the Piccole Isole Project. The study complies with current Italian laws and was performed under permit from the Regione Lazio.
Funding The study was supported by the FAR of the University of Ferrara and start-up funds of the University of Vienna and University of Veterinary Medicine, Vienna, to LF.

\section{Compliance with ethical standards}

Conflict of interest The authors declare that they have no conflict of interest.

Open Access This article is licensed under a Creative Commons Attribution 4.0 International License, which permits use, sharing, adaptation, distribution and reproduction in any medium or format, as long as you give appropriate credit to the original author(s) and the source, provide a link to the Creative Commons licence, and indicate if changes were made. The images or other third party material in this article are included in the article's Creative Commons licence, unless indicated otherwise in a credit line to the material. If material is not included in the article's Creative Commons licence and your intended use is not permitted by statutory regulation or exceeds the permitted use, you will need to obtain permission directly from the copyright holder. To view a copy of this licence, visit http://creativecommons.org/licenses/by/4.0/.

\section{References}

Adamík P, Emmenegger T, Briedis M, Gustafsson L, Henshaw I, Krist M, Laaksonen T, Liechti F, Procházka P, Salewski V, Hahn S (2016) Barrier crossing in small avian migrants: individual tracking reveals prolonged nocturnal flights into the day as a common migratory strategy. Sci Rep 6:21560

Bairlein F (1995) European-African songbird migration network Manual of field methods. Revised edition. Wilhelmshaven, Jade Bight

Bauchinger U, Wohlmann A, Biebach H (2005) Flexible remodeling of organ size during spring migration of the Garden Warbler (Sylvia borin). Zoology 108:97-106

Buler JJ, Lyon RJ, Smolinsky JA, Zenzal TJ Jr, Moore FR (2017) Body mass and wing shape explain variability in broad-scale bird species distributions of migratory passerines along an ecological barrier during stopover. Oecologia 185:205-212

Buler JJ, Moore FR (2011) Migrant-habitat relationships during stopover along an ecological barrier: extrinsic constraints and conservation implications. J Ornithol 152(Suppl. 1):S101-S112

Cecere JG, Matricardi C, Frank B, Imperio S, Spina F, Gargallo G, Barboutis C, Boitani L (2010) Nectar exploitation by songbirds at Mediterranean stopover sites. Ardeola 57:143-157

Cecere JG, Spina F, Jenni-Eiermann S, Boitani L (2011) Nectar: an energy drink used by European songbirds during spring migration. J Ornithol 152:923-931

Cooper WE Jr, Pyron RA, Garland T Jr (2014) Island tameness: living on islands reduces flight initiation distance. Proc R Soc Lond B 281:20133019

Deppe JL, Ward MP, Bolus RT, Diehl RH, Celis-Murillo A, Zenzal TJ Jr, Moore FR, Benson TJ, Smolinsky JA, Schofield LN, Enstrom DA, Paxton EH, Bohrer G, Beveroth TA, Raim A, Obringer RL, Delaney D, Cochran WW (2015) Fat, weather, and date affect migratory songbirds' departure decisions, routes, and time it takes to cross the Gulf of Mexico. Proc Natl Acad Sci USA 112:E6331-E6338

Ferretti A, Maggini I, Lupi S, Cardinale M, Fusani L (2019a) The amount of available food affects diurnal locomotor activity in migratory songbirds during stopover. Sci Rep 9:19027 
Ferretti A, Rattenborg NC, Ruf T, McWilliams SR, Cardinale M, Fusani L (2019b) Sleeping unsafely tucked in to conserve energy in a nocturnal migratory songbird. Curr Biol 29:2766-2772

Fusani L, Cardinale M, Carere C, Goymann W (2009) Stopover decision during migration: physiological conditions predict nocturnal restlessness in wild passerines. Biol Lett 5:302-305

Gargallo G, Barriocanal C, Castany J, Clarabuch O, Escandell R, López-Iborra G, Rguibi Idrissi H, Robson D, Suárez M (2011) Spring migration in the western Mediterranean and NW Africa: the results of 16 years of the Piccole Isole project. Monogr Mus Ciències Nat 6:1-364

Goymann W, Spina F, Ferri A, Fusani L (2010) Body fat influences departure from stopover sites in migratory birds: evidence from whole-island telemetry. Biol Lett 6:478-481

Grattarola A, Spina F, Pilastro A (1999) Spring migration of the Garden Warbler (Sylvia borin) across the Mediterranean Sea. J Ornithol 140:419-430

Hothorn T, Bretz F, Westfall P (2008) Simultaneous inference in general parametric models. Biometrical J 50:346-363

Ktitorov P, Bairlein F, Dubinin M (2008) The importance of landscape context for songbirds on migration: body mass gain is related to habitat cover. Landsc Ecol 23:169-179

Kuenzi AJ, Moore FR, Simons TR (1991) Stopover of neotropical landbird migrants on East Ship island following trans-gulf migration. Condor 93:869-883

Lester LA, Gutierrez Ramirez M, Kneidel AH, Heckscher CM (2016) Use of a Florida Gulf Coast barrier island by spring trans-gulf migrants and the projected effects of sea level rise on habitat availability. PLoS ONE 11:e0148975

Lupi S, Maggini I, Goymann W, Cardinale M, Rojas Mora A, Fusani L (2017) Effects of body condition and food intake on stopover decisions in garden warblers and European robins during spring migration. J Ornithol 158:989-999

Martin TG, Chadès I, Arcese P, Marra PP, Possingham HP, Norris DR (2007) Optimal conservation of migratory species. PLoS ONE 2:e751

McCabe JD, Olsen BJ (2015) Tradeoffs between predation risk and fruit resources shape habitat use of landbirds during autumn migration. Auk 132:903-913

Mehlman DW, Mabey SE, Ewert DN, Duncan C, Abel B, Cimprich D, Sutter RD, Woodrey M (2005) Conserving stopover sites for forest-dwelling migratory landbirds. Auk 122:1281-1290

Meschini A, Frugis S (1993) Atlante degli uccelli nidificanti in Italia. Istituto Nazionale per la Fauna Selvatica, Roma

Messineo A, Grattarola A, Spina F (2001) Ten years of activity of the Progetto Piccole Isole: years 1988-1997. Biol Cons Fauna 106:77-240

Moore FR, Aborn DA (1996) Time of departure by Summer Tanagers (Piranga rubra) from a stopover site following spring trans-gulf migration. Auk 113:949-952

Moore FR, Covino KM, Lewis WB, Zenzal TJ Jr, Benson TJ (2017) Effect of fuel deposition rate on departure fuel load of migratory songbirds during spring stopover along the northern coast of the Gulf of Mexico. J Avian Biol 48:123-132

Moore FR, Kerlinger P (1987) Stopover and fat deposition by North American wood-warblers (Parulinae) following spring migration over the Gulf of Mexico. Oecologia 74:47-54

Moore FR, Kerlinger P, Simons TR (1990) Stopover on a Gulf Coast barrier island by spring trans-gulf migrants. Wilson Bull 102:487-500
Morris SR, Pusateri CR, Battaglia KA (2003) Spring migration and stopover ecology of Common Yellowthroats on Appledore island, Maine. Wilson Bull 115:64-72

Morris SR, Richmond ME, Holmes DW (1994) Patterns of stopover by warblers during spring and fall migration on Appledore island, Maine. Wilson Bull 106:703-718

Nemeth Z (2009) Observation of daytime sleep-like behavior in a migratory songbird during stopover. Wilson J Ornithol 121:644-646

Peig J, Green AJ (2009) New perspectives for estimating body condition from mass/length data: the scaled mass index as an alternative method. Oikos 118:1883-1891

Piersma T, Lindström $\AA$ (1997) Rapid reversible changes in organ size as a component of adaptive behavior. Trends Ecol Evol 12:134-138

Pilastro A, Spina F (1997) Ecological and morphological correlates of residual fat reserves in passerine migrants at their spring arrival in southern Europe. J Avian Biol 28:309-318

R Core Team (2019) R: a language and environment for statistical computing. R Foundation for Statistical Computing, Vienna, Austria. https://www.R-project.org/

Saino N, Rubolini D, von Hardenberg J, Ambrosini R, Provenzale A, Romano M, Spina F (2010) Spring migration decisions in relation to weather are predicted by wing morphology among transMediterranean migratory birds. Funct Ecol 24:658-669

Schaub M, Jenni L, Bairlein F (2008) Fuel stores, fuel accumulation, and the decision to depart from a migration stopover site. Behav Ecol 19:657-666

Schmaljohann H, Eikenaar C (2017) How do energy stores and changes in these affect departure decisions by migratory birds? A critical view on stopover ecology studies and some future perspectives. J Comp Physiol A 203:411-429

Schwilch R, Mantovani R, Spina F, Jenni L (2001) Nectar consumption of warblers after long-distance flights during spring migration. Ibis 143:24-32

Schwilch R, Piersma T, Holmgren NMA, Jenni L (2002) Do migratory birds need a nap after a long nonstop flight? Ardea 90:149-154

Spina F, Massi A, Montemaggiori A, Baccetti N (1993) Spring migration across central Mediterranean: general results from the "Progetto Piccole Isole". Vogelwarte 37:1-94

Suomala RW, Morris SR, Babbitt KJ (2012) Comparison of migrant songbird stopover ecology on two islands in the Gulf of Maine. Wilson J Ornithol 124:217-229

Tenan S, Spina F (2010) Timing and condition-related effects on recapture probability, mass change, and stopover length of spring migrating songbirds on a small Mediterranean island. Ardeola $57: 121-132$

Yong W, Moore FR (1993) Relation between migratory activity and energetic condition among thrushes (Turdinae) following the passage across the Gulf of Mexico. Condor 95:934-943

Yong W, Moore FR (1997) Spring stopover of intercontinental migratory thrushes along the Northern coast of the Gulf of Mexico. Auk 114:263-278

Publisher's Note Springer Nature remains neutral with regard to jurisdictional claims in published maps and institutional affiliations. 